\title{
The Jurisprudence of Compliance and Enforceability of Environmental Protection Laws in Nigeria
}

\author{
Odinga Blessing Chiwendu \\ Faculty of Law, Rivers State University \\ Uche Jack Osimiri \\ Professor of Law, Faculty of Law, \\ Rivers State University
}

\begin{abstract}
The compliance and enforceability of the laid down laws and procedures for sustainable development as inferred from the laws and standard for environmental protection in Nigeria has become one of great concern as the unsustainable use of the of the environment has kept the environment in an in secured state as well as placed the life's and health of the people in danger. With the effect of the activities of the oil and gas industries and the xray of the laws put in place for environmental protection especially as it relates to the penalties, the line of reasoning is broadened as to know why the high rate of pollution amidst the constitutional provisions and otherwise. The draftsmen created lapses in the environmental protection laws however, the compliance and enforcement of the laws the ways they are; still have the capacity to maintain a good and sustainable environment while development continues. However, the constitutional provisions on environmental protection are not exhaustive and it has attracted so much judicial activism which has always ended up not been complementary not until just recently in 2019 the Supreme Court retted otherwise as until then, it has resulted in the miscarriage of Justice. The courts needed to adopt a firm approach dealing with environmental justice hence it has to do with life and health of the people who have been guaranteed fundamental right to life in the constitution. Stiffened penalty will sure streamline the activities in relation to environmental protection.
\end{abstract}

Keywords: Compliance, Enforceability, Penalty, Environmental protection laws

DOI: $10.7176 / J L P G / 93-16$

Publication date: January $31^{\text {st }} 2020$

\section{Introduction}

Law is simply a laid down rule/standard to guard the behavioral pattern of a people. It then means that before a law is made, it should put into consideration, the behavioral pattern of a people to be able to have effect especially as regarding compliance and enforcement of the Law. Environmental protection Laws have been put in place for instance the Environmental impact Assessment Act which main aim is to foresee the successful adaptation of the desired project with the environment.

It is however, not out of place to ask if there are no enforcement agencies due to the high rate of non-compliance. This research is to discuss briefly the sanctions accompanying the laws and the enforcement mechanisms and examine to what extent they can guarantee compliance.

\section{Clarification of key terms}

\subsection{Compliance}

Compliance generally means conforming to a rule, such as a specification, policy, standard or law. It is either a state of being in accordance with established guidelines or specifications, or the process of becoming so $^{1}$. Compliance is further said to be a prevalent business concern, partly because of an ever-increasing number of regulations that require companies to be vigilant about maintaining a full understanding of their regulatory compliance requirement ${ }^{2}$.

It has also been defined in its business sense to mean a company meeting its legal obligations, often to protect the health, safety and welfare of others. ${ }^{3}$ Compliance reduces or exonerates from fines, penalties, law suits or even shutdown of your business ${ }^{1}$.

\footnotetext{
${ }^{1}$ M. Rouse, 'Definition of Compliance' (2015) <https://searchdata management.techtarget.com>accessed 5th December, 2019.

${ }^{2}$ Ibid

${ }^{3} \mathrm{~S}$ Ashe- Edmunds, 'importance of compliance of business' (2018) $<$ https;//smallbusiness.chron/com $>$ assessed $5^{\text {th }}$ December, 2019.
} 


\subsection{Enforcement}

Enforcement is the process of ensuring compliance with laws, regulations, standards and Government attempt to bring about successful implementation of policies by enforcing laws and regulations. It further means when people are made to obey a rule, law, standard and others. ${ }^{2}$ It has also been defined as the process of making people obey a law or making a particular situation happen or be accepted. ${ }^{3}$ Enforcement has been proven to be a difficult task especially as it relates to environmental justice. Enforcement is where the effectiveness of a law lays hence if there is a law, and it is not enforced. It is as good as there is no law.

\subsection{Penalty}

Penalty is simply a punishment imposed for breaking a law, rule or other. ${ }^{4}$ The definition seems exhaustive but it is important to state that penalties should be fixed after a clear study of the behavioral pattern of a people for it to serve as a deterrent or have effect. Where the penalty imposed for breaking a law is not such as can deter committal, then it is at best a literature.

\subsection{Jurisprudence}

Jurisprudence is the theory or philosophy of law. Philosophy on the other hand, is the study of the fundamental nature of knowledge, reality and existence, especially when considered as an academic discipline. It is also the theory or attitude that acts as a guiding principle for behaviour. Theory on its own is a supposition or a system of ideas intended to explain something especially one based on general principles independent of the thing to be explained. It is also an idea used to account for a situation or justify course of action.

\section{Compliance and Enforcement of Environmental Laws in Nigeria.}

The constitution is the supreme law of the land and supersedes in the event of contradiction with any law on its provisions. The basis for environmental law/policy in Nigeria is the constitution ${ }^{5}$. Section 20 of the constitution provides that is the state that is empowered to protect and improve the environment and safeguard the water, air and land, forest and wild life of Nigeria. ${ }^{6}$

The Federal ministry of environment is empowered to administer and enforce environmental laws in Nigeria and environment laws are put in place to check, protect and preserve the environment. The United Nations saw the need for environmental protection and severally conveyed conferences/convention to maintain a balanced and good environment however, in Nigeria not until the 1988 Koko incident that created awareness of the impact of environmental pollution thereby brought about promulgation of laws as well as formation of agencies to regulate environmental laws/standards.

The harmful wastes (Special Criminal Provisions) Act 1988, Federal Environmental protection Agency (FEPA) Act, the Environmental Impact Assessment and others are some of the environmental laws put in place and presently, there are others laws on environmental protection yet, pollution has remained unabated especially arising from the oil and gas industries. ${ }^{7}$

Omaka $^{8}$ in his book stated that environmental impact assessment Act is a good tool for sustainable development despite its bad drafting but the problem is with compliance. Enforcement on the other hand on environmental issues, appears to be more of papers write ups as in practice, it appears void. In Oronto Douglas V Shell Petroleum Development Company Limited Ors ${ }^{9}$, The Chief went to court to enforce Shell compliance with the environmental impact Assessment conditions before continuing with the project only addressed the Chief as an activist but lacked the capacity to bring such matter before the court. However, just recently, the Supreme Court of Nigeria took a bold step to decide separately as sister's courts in other jurisdictions like India has done earlier.

\footnotetext{
${ }^{1}$ ibid

${ }^{2}$ Longman Dictionary of contemporary English <https://www.idoceonline.com.>assesed 5th December, 2019.

${ }^{3}$ Cambridge Dictionary $<$ from dictionary. Cambridge $>$ assessed $5^{\text {th }}$ December, 2019.

${ }^{4}$ Penalty/ Definition of penalty at Dictionary.com $<$ https.//www.dictionary.com browse $>$ assessed $6^{\text {th }}$ December, 2019.

${ }^{5}$ CFRN 1999 LFN 2004 (as amended).

${ }^{6} \mathrm{Ibid}$

${ }^{7}$ O.C Eneh and V. C. Agbazue, 'protection of Nigeria's Environment: A critical policy review journal of Environment science and technology(2011) vol. 4;490 -487.

${ }^{8}$ A. Omaka, 'Land International and municipal environmental law (LUC Bages 2012)

${ }^{9}$ [1994] 8 NWLR LFN 2004
} 
The Supreme Court of Nigeria in centre for oil pollution water v. NNPC ${ }^{1}$ delivered on the $20^{\text {th }}$ day of July 2018 but reported on $15^{\text {th }}$ April 2019, stated that the term locus Standi is Latin and literally means place of standing as well as the legal right or capacity to bring an action before the court.This was a case of oil spill in Acha Community, Abia state and the issue or locus standi was projected.

\section{Environmental Liability}

Environmental crime is said to be an activity or existing condition that does not comply with environmental law or regulation. This include smoke or the emissions from local industrial facilities; tampering with emission control, improper treatment, storage or disposal of hazardous wastes; exceeding pollutants limits at publicly owned waste water treatment plants; unpermitted dredging or filing of waters and wetlands; any unpermitted industrial activity. It is important to highlight that nesrea used environmental harm rather than environmental crimes $^{2}$

4.1. A Critical examination of the liabilities is imperative.

a. National Environmental Standard Regulation and Enforcement Agency (2007) (as amended)

This NESREA $\mathrm{Act}^{3}$ also centers on the air quality and the atmospheric protection stating that the agency may make regulations setting specifications and standards to protect and enhance the quality of Nigeria's air resources, so as to promote the public health or welfare and the natural development and productive capacity of humans, marine and plant life.

The Act ${ }^{4}$ borders on Ozone protection providing that the Agency shall in collaboration with other relevant agencies; embark on programmes for the control of any substance practices, process or activity which may reasonably be anticipated to affect the stratosphere, especially ozone in the stratosphere when such effects may reasonably be anticipated to endanger public health or welfare.

Section 22 and Section 23 relates to originating control noise from industrial, commercial, domestic, sports, recreational, transportation or other similar activities and federal water quality standards. Section 23 (1) provides that in collaboration with other relevant agencies make regulations for the purpose of protecting public health or welfare and enhancing the quality of water to serve the purpose.

However, underlying these provisions, the liability for defaulters is thus:

i) Section 20(4) and 21(1) NESREA: where an offence is committed by a corporate body, it shall on conviction be liable to a fine not exceeding two million naira and an additional fine of fifty thousand naira for every day the offence subsist. Now, this liability looks appealing but considering the nature in which the Nigerian man and his inhabitants respond to law, it seems not adequate hence when Timariv was operational in Rivers State, they had steady customers but kidnapping was scarcely heard of when under Governor Amaechi, it was matched with death penalty;

ii) Section 22 and 23 says where one is convicted; the liability is a fine not exceeding five hundred thousand naira and an additional fine of ten thousand naira for every day the offence subsists.

The value of money can never be a match to the value of life. A stringent penalty can attract fear and Colgate a responsible style and mode of doing things.

iii) Section 24, 26, and 27 NESREA : This to the effect that the body corporate where it commits an offence by contravening the provisions of these sections shall be liable to a fine not exceeding one million naira and an additional fine of fifty thousand per day as long as the offence subsist.

This means that for instance oil spills the company may decide not to clean up for one month or more and will only pay fifty thousand naira multiply the one month which is just a token to the company whilst the host community remain with their life at great risk of death, sickness and others.

\section{b. Environmental Impact Assessment}

\footnotetext{
${ }^{1}$ (2019) 5 NWLR (Pt 1666) 518

${ }^{2}$ NESREA, 'Environmental violation' (2018) $<$ http://www.nesrea.gov.ng/contact.us/environmentalvoilations/> accessed $25^{\text {th }}$ May 2019

${ }^{3}$ NESREA establishment 2007 s $20(1)$

${ }^{4}$ NESREA establishment 2007 s 21 (1)
} 
This can actually sustain as well as promote sustainable development but regrettably, the penalty attached to defaulters has no deterring effect and it states that in the case of an individual, it is one hundred thousand naira or five years imprisonment and in the case of a corporation fine of not less than fifty thousand naira and not more than one hundred thousand naira.

What actually bars the manager in charge of inspection, the officer in charge of the specific sector that defaulted from being an individual liable to five (5) years imprisonment and also the corporation paying the fees. So offensive that individual is liable to one hundred thousand naira whereas corporation to fifty thousand naira whereas it is proven that these oil and gas companies are giant polluters of our environment.

\section{c. $\quad$ Federal Solid and Hazardous Waste Management Regulations}

This Act $^{2}$ which contains 108 sections and schedules only made individuals liable but no provision for corporate bodies' liability. This is indeed incredible. The giant polluters are not accountable as such any liability / penalty melted out on them.

\section{d. The Harmful Waste (Special Criminal Provisions) Act}

It seems reasonable and all-encompassing as it stated that the liability of organization is through its members who shall be punished accordingly. However, the Act did not define what is meant by punished accordingly. The Act $^{3}$ States that where a crime has been committed by a body corporate, and it is proved that it was committed with the consent or connivance of or is attributable to any neglect on the part of a Director, manager, secretary or any other similar officer of the body corporate or b. Any other person purporting to act in the capacity of a director, manager, secretary or other similar officer, he as well as the body corporate shall be guilty of the crime and shall be liable to be proceeded against and punished accordingly.

\section{e. Nuclear Safety and Radiation Protection Act, (CAP N142LFN 2004)}

Section 43 (3) of the $\mathrm{Act}^{4}$ provides thus:

Where an offence under this Act which has been committed by a body whether corporate or not provided it has been committed with the consent or connivance of or is attributable to any act or default on the part of any person or persons in apparent control of the body, the person or persons in apparent control as well as the body shall be deemed to have committed the offence and shall be liable to be proceeded against and punished accordingly.

The section did not prescribe the penalty. However, it is inferred to be the same as that prescribed for an individual under section 50 of the act thus:

A person who:

a. Contravenes any of the provisions of this Act; or

b. Does not comply with a limitation or condition subject to which he is registered, exempted or licensed under this Act, is guilty of on offence and sable on conviction to a fine not less than $\mathrm{N} 100,000$ or more than $\mathrm{N} 3,000,000$ or to imprisonment for a minimum term of not less than two years or more than ten years or both fine and imprisonment.

In addition the authority may cancel, revoke or suspend any registration, exemption or license that might have been or granted the person. This provision seems encouraging but yet to see any case where it has been implemented to its letter

\section{f. Nigerian Urban and Regional Planning Act}

The Act $^{5}$ makes it an offence to disobey a stop work order, the penalty therefore is a fine not exceeding ten thousand naira and in the case of a corporation a fine not exceeding fifty thousand. Section 60 says where a developer contravenes the provisions of a planning law or any regulation made pursuant to a law.

${ }^{1}$ EIA (Act) CAP E12LFN 2004

${ }^{2}$ F.SHWMR 1991

${ }^{3}$ HWSCP Act Cap 111 LFN 2004

${ }^{4}$ NSRP Act Cap n142, LFN 2004

${ }^{5}$ NURP Act Cap N138, LFN 2004; s 59 
The penalty shall on summary conviction be liable to imprisonment for a term not exceeding three months or to a fine not exceeding one thousand naira or to both imprisonment and fine. On conviction for indictment, be liable to imprisonment for a term not exceeding twelve months or to fine not exceeding two thousand Naira or to both imprisonment and fine. In the case of a corporate body, the liability is a fine of five thousand Naira.

\section{g. Water Resources Act}

The $\mathrm{Act}^{1}$ makes it an offence for anyone to contravene or fail to comply with any provisions of the Act and makes any defaulter liable upon conviction to a fine not exceeding two thousand naira or to a term of imprisonment not exceeding six months or to both such fine and imprisonment, and in the case of a continuing offence to an additional fine not exceeding one hundred naira daily or part of a day that the offence continues. Section 18 (2) which is the penalty section provides that where an offence under this Act has been committed by a body corporate or firm or other association of individuals, a person who at the time of the commission of the offence was an officer thereof or was purporting to act in such capacity, is severally guilty of that offence and liable to be prosecuted against and punished for the offence in like manner as if he had himself committed the offence, unless he proves that the act or omission constituting the offence took place without his knowledge, consent or connivance.

\section{h. Oil Pipelines Act}

Section 32 of the Act specifically provides for offences by corporate bodies thus: where an offence under this Act which has been committed by a body corporate is proved to have been committed with the consent or connivance of, or to be attributable to any neglect on the part of, any director, manager, secretary, or other similar officer of the body corporate, or any person purporting to act in any such capacity, he, as well as the body corporate shall be deemed to be guilty of that offence and shall be liable to be proceeded against and punished accordingly. ${ }^{2}$.We have looked at the criminal liabilities of several environmental protection Acts and it becomes imperative to view the compliance and enforcement mechanisms hence it is indeed mind-tasking to know why all these penalties exist and laws to keep and maintain a sustainable environment yet the pollution continues.

\section{i. National Oil Spill Detection Regulatory Agency}

An oil spiller is by this Act to report any oil spill to the Agency in writing, by fax or electronic mail not later than 24 hours after the occurrence of an oil spill in default of which the failure to report shall attract penalty sum of two million naira for failure to report the occurrence. The failure to clean up the impacted site, to all practical extent including action plan for remediation within two weeks of the occurrence of the spill in accordance with the polluter pays principle shall constitute an offence and on conviction the oil spiller shall be liable to a fine not exceeding five million naira or to imprisonment for a term not exceeding (two) 2years or to both fine and imprisonment. The notice required under subsection (2) of this section shall be deemed to have been made, if delivered at the nearest zonal or field office of the Agency closer to the impacted site or the National Control and Response Centre within the time stipulated in subsection (2) of this section. ${ }^{3}$

\section{It is important to state that NOSDRA, is not without challenges. Some of the challenges are:} the event of major or disastrous oil spill ( Tier 3) section 7 (g)(i), to be performed in collaboration with other agencies co-opted to undertake and supervise all the provisions in the second schedule to NOSDRA Act. This seems to us a strong task given the fact that the number of agencies involved in the co-operation and coordination for a quick response action in the event of a disastrous oil spillage is not an easy process to manage e.g. Nigeria Army, Navy, Air force and all other related ministries and parastatals. The modus operandi to elicit the corporation of these other agencies is not specified.

b. Funding: Under part V, section 11(a)-(h) of the NOSDRA Act 2006 as amended the agency (NOSDRA) depends solely on the annual subvention from Federal Government to fund its activities. The difficulties associated with accessing federal funds is obvious and cannot be relied on to effect the 24 hours expected clean up by the organization.

Polluter-pay-principle: This principle of funding exposes the vulnerability of NOSDRA in providing funds for the expeditious clean-up in the event of a three (3) tier spillage. We are compelled to juxtapose this system with

${ }^{1}$ WRA Act Cap W2LFN 2004

2 .OPA Cap 07 LFN 2004 s 32

${ }^{3}$ Section $6(2,3, \& 4)$ Ibid 
the funding regime in the United States on similar legislation and noticed that their funding regime is far much better and proactive than their Nigeria counterpart. In the US their Oil pollution Act, 1990, created the burden of clean up and damages on. ${ }^{1}$

\section{Implementation and Enforcement Mechanism for environmental pollution: A case for Nigeria.}

This work is suggestive that the three tiers of government are to be blamed for the non-compliance to environmental laws in Nigeria as the major culprits (oil and gas industries) are investment partners with our government who placed right to life as a fundamental human right in chapter four of our 1999 constitution but placed environmental safety/protection in chapter two and made it non-justifiable by the provisions of section (6) (6) (c) invariably saying you do not have any right of environmental protection which apply that there is no right to life hence the environment secures one's health and life without health is zero.

A combined effect of section 1 (2) (a) and Section 7 (a) of the NESREA Act empowers the agency with enforcement capacity. It has encapsulated in it, the power to enforce and ensure compliance with environmental standards, regulation, laws, policies, rules and guideline, ${ }^{2}$ and this power includes enforcement of sustainable development.

The implication of NESREA being the only one having the power to enforce and ensure compliance, individuals, non-governmental organizations (NGO's), and even local communities have no locus standi to bring claims for the enforcement/ compliance like the case where the court described the chief as an activist and lacked locus standi whereas the man came to court to ask that the corporation (Shell and others) should not be allowed to commence the project in Bonny Island hence the corporation has not completed the E.1.A provision as to whether the project is safe or not $^{3}$ is obsolete in the face of the challenges posed by environmental degradation/pollution.

The effect of this is that some Nigerians go to seek environmental justice outside Nigeria to avoid locus standi issue and this is a clog to the implementation and enforcement of sustainable in Nigeria. However, this challenge can be rectified and it is by the National Assembly including/ integrating sustainable development into the 1999 constitution and or like the bold step by the Supreme Court in center for oil pollution water v. NNPC. ${ }^{4}$ The fact remains that sustainable development should be inculcated into right to life under chapter 4 hence if you have a right to life under the constitution and in real life this right is deprived you through an unhealthy/ an unsafe environment which we know includes food (land), air, water and not just for the present but unborn generation do you still have a right to life guaranteed under chapter 4 of the constitution ${ }^{5}$

The National Conference held in 2014 stated in its recommendations of constitutional provisions in the environment that there is vital need to preserve the integrity of the Nigerian environment and secure its sustainability for both present and future generation through a clear and direct stipulation of Sustainable development in the constitution ${ }^{6}$

To further strengthen implementation and enforcement of sustainable development which is the core aim of environmental protection by lifting or transferring/moving section 20 of the constitution from chapter two to chapter four (iv) and amending also section 17 (2) (a) on economic objective and section 17 (2) (d) on exploration of natural resources. ${ }^{7}$

Authors/ writers have argued that to give locus standi to NGO's, individuals, local communities, Section 20 before being transferred to chapter IV should be amended thus inserting the word sustainability just after the word environment.

\footnotetext{
${ }^{1} \mathrm{~J}$ Joseph, 'The legislative and institutional framework of environmental protection in the oil and gas sector in Nigeria- a review' (2017)<https.//www.Researchgate.net> accessed on 31 ${ }^{\text {st }}$ October, 2019

${ }^{2}$ E Okon, 'The Legal statutes of Sustainable Development in the Nigerian environmental law' (AfeBabalola university journal of sust.Dev.law of policy' 2016) <https:dxor.org/> Vol. 7 12, 2016

3 (1994) 6 Nwlr (pt32) 258 in oronto Douglas v SPDC\&ors

4 (1999) 5 NWLR (Pt 1666) 518

${ }^{5}$ CFRN 1999 Cap C23LFN 2004; S 3 (1)

${ }^{6} \mathrm{~J}$ E. Occer, 'main report of the National Conference' (2014) $130<\mathrm{https}: / /$ www.researchgate $>$ accessed $31^{\text {st }}$ October, 2019

${ }^{7} \mathrm{C}$ T emejuru, 'Wither ${ }^{7}$ (1994) 6 Nwlr (pt32) 258 in oronto Douglas v SPDC\&ors

${ }^{7}$ (1999) 5 NWLR (Pt 1666) 518

${ }^{7}$ CFRN 1999 Cap C23LFN 2004; S 3 (1)

${ }^{7}$ J E. Occer, 'main report of the National Conference' (2014) $130<$ https://www.researchgate $>$ accessed $31^{\text {st }}$ October, 2019

Nigeria' (Journal of Law Policy and Globalization 2015)
} 
To Read Thus:

The State shall protect and improve the environmental sustainability and safeguard the water, air and land, forest and wildlife of Nigeria.

Advocate also that sub section 2 should read:

Where the state fails to perform its duties under subsection (i) of this section, individuals, nongovernmental organization of local communities may take legal actions to enforce the said subsection. ${ }^{2}$

Summarily there are bodies for effective implementation of the environmental protection laws like NESREA, NORDRA but these subsidiary institutions due to lack of fund and logistics on one hand and corruption of the officer on the other hand cannot function well. Secondly, there are parastals under government ministries like federal ministry of environment. This study on the issue of enforcement has it to add that the courts pronouncement and the execution of the court pronouncement by the police especially if there were community policing system hence the community feels the pains and impacts of the pollution more.

\section{Conclusion}

The environment is an essential part of man's life. It also includes plants and animals life and so should be kept in a good condition. There is therefore need to promote the life's of citizens by enforcing compliance to environmental laws even though they may not be adequate especially with regards to the penalties.

\section{Recommendation}

In the light of the above the following recommendation are proffered as follows:

1. Laws should be made putting into consideration the life style of a people for example where a law has a stringent and harsh sanction like life imprisonment or imprisonment with fine attached to it, in Nigeria it promotes compliance.

2. The monitoring and inspection team/agencies of environmental protection laws should be made productive by proper funding and availability of the mechanisms.

\footnotetext{
${ }^{1}$ E. E Okon, ' the legal status of sustainable development' (Journal of AfeBabalola University of Sustainable development and policy vol. 7:2, 2016) 132

${ }^{2}$ Ibid
} 